Gender, Place \& Culture

A Journal of Feminist Geography

ISSN: 0966-369X (Print) 1360-0524 (Online) Journal homepage: http://www.tandfonline.com/loi/cgpc20

\title{
Opening up a space for women: matinees in Izmir Culture Park
}

\section{Meltem Eranıl Demirli \& Meltem Ö. Gürel}

To cite this article: Meltem Eranıl Demirli \& Meltem Ö. Gürel (2018): Opening up a space for women: matinees in Izmir Culture Park, Gender, Place \& Culture, DOI: 10.1080/0966369X.2018.1484701

To link to this article: https://doi.org/10.1080/0966369X.2018.1484701

曲 Published online: 17 Nov 2018.

Submit your article to this journal

Џ Article views: 55

View Crossmark data $₫$ 


\title{
Opening up a space for women: matinees in Izmir Culture Park
}

\author{
Meltem Eranıl Demirli ${ }^{\mathrm{a}}$ and Meltem Ö. Gürel ${ }^{\mathrm{b}}$ \\ ${ }^{a}$ Department of Interior Architecture and Environmental Design, Bilkent University, Ankara, \\ Turkey; ${ }^{\mathrm{b}}$ Department of Architecture, Bilkent University, Ankara, Turkey
}

\begin{abstract}
This article explores how women's practices transformed abstract space into lived space in the context of women's matinees in the entertainment venues of Izmir Culture Park, a historical marker of Turkish modernity. Drawing on collective memory, Lefebvrian spatial theories, and gender studies, the article sets out an analytical framework through which to explore women's spatial preferences and performances. Engaging with oral histories and archival material, the study reads women's agency in 1970s matinees, arguing that these events opened up an alternative public space for women to liberate themselves by applying their own rituals and tactics in this space. They thus added new layers of meaning about women's spatiality to the historicity of the park.
\end{abstract}

\section{ARTICLE HISTORY}

Received 29 January 2017

Accepted 11 February 2018

\section{KEYWORDS}

Izmir Culture Park; matinee; memory; modernity; social space; women's agency

\section{Introduction}

An entertainment culture situated in the physical environment of Turkey's casinos (called gazino throughout this article) signified a means of modernity through their practices following the foundation of the Republic of Turkey in 1923. As a public place for live music and shows, often with a café or restaurant and evening dancing, gazinos accommodated contemporary relationships between women and men in a Muslim dominated society. According to Gürel $(2011,165)$, in housing mixed-gender activities involving music, dancing, and dining (gazinos were not gambling venues), these spaces provided "a social structure ..., which work to connect localities to [global] processes of modernization and westernization in the Turkish context." The gazino environment offered a public space for upper-class women to internalize their contemporary socio-cultural status, public presence, and civic roles (in great contrast to their Ottoman predecessors) in an urban context.

CONTACT Meltem Ö. Gürel meltem.gurel@yasar.edu.tr $\Theta$ Department of Architecture, Bilkent University, 06800 Bilkent, Ankara, Turkey. 
However, though manifesting women's 'new' abilities and providing an avenue to participate in the public space and adapt to modern lifestyles, the (initially evening) gazino programs simultaneously restricted and coded women's behaviour. Usually accompanied by husbands or brothers while attending events, women continued to experience patriarchal surveillance, which arguably restricted their mannerisms and conduct to ways considered appropriate for an ideal woman, whether wife, sister, or daughter.

By the 1970s, however, gazino practices had reached a wider audience including the middle-class urban woman - due to Turkey's changing social, political, and economic dynamics. The continuously transforming status of these women, and their desire for freer self-expression, encouraged greater interest in matinees as a regenerative social space. With evening television broadcasts newly vying for attention, daytime gazino programs became more widespread. What was the significance of this matinee space in co-creating women's desires? What were patrons' practices and experiences? In accommodating these practices and mediating women's participation in public life, how did the matinee give women opportunities to do gender differently? With such questions in mind, we analyze the meanings of women's matinee practices in Izmir Culture Park's (ICP) gazinos in the 1970s.

\section{Izmir Culture Park and female patrons in daily reality}

Established in 1936 as an exemplary public space in modern Turkey, ICP housed numerous gazinos, presenting popular singers and attracting crowds from all over the country, especially during Izmir's annual International Fair between August 20 and September 20. Thus, ICP was an illustrative site of gazino culture and matinee praxes, playing a significant role from its beginning in defining the social life and entertainment practices of locals and visitors (Feyzioğlu 2011). Similar to its counterparts in other cities, ICP was conceived as a national urban space mediating modern habits, new social interactions and lifestyles, and demonstrating a new citizenship based on republican precepts (Kolluoğlu 2007, 230; Gürel 2011, 170). Through its gazinos, ICP successfully reproduced the daily urban realities of physical space, as discussed by Lefebvre. Existing between these urban realities, it constituted a social space that carried close associations with both perceived and lived space (Lefebvre [1974] 1998). In the Lefebvrian understanding of social space, production and reproduction coexist: while planners, architects, bureaucrats, and other authorities produce conceived space, users reproduce it through their practices and mentally reconstruct it. A certain tension and resistance are thus built on the three layers of social space (conceived, perceived, lived; originally defined by Lefebvre as representations of space, representational space, and spatial practices) as they complete each other. This 
tension ensures continuity and some degree of cohesion (Lefebvre [1974] 1998), creating a space of representation and resistance while its existence depends on the conceived space (Allen 1999).

Izmir Culture Park resisted urban reality by reproducing daily reality through its public spaces for women at a time when their leisure activities had normative limitations. Women could not be out at night without a man from the family, alcohol consumption was restricted in public entertainment facilities, and only men were allowed to socialize in coffeehouses. Since ICP's social space was strongly connected to its contemporary culture and period, its physical space also changed as the community, context, and daily practices changed. Accordingly, we critically examine ICP gazinos by highlighting how these spaces changed not only physically but also socially through women's practices by and in the 1970s.

Importantly, we explore in depth how women's practices transformed abstract space into lived space. Drawing on collective memory, Lefebvrian spatial theories, and gender studies, we develop an analytical framework for exploring women's spatial preferences and performances. The article's main objectives are twofold: contributing to gender studies by studying ICP's small-scale gazino/matinee spaces and investigating the constraints affecting women's performances in these public spaces. It therefore focuses on the public space of the matinee, gathering information from the material traces and narrations of its users' recollections of the 1970s, while constructing hybrid notions of space, women, and memory.

\section{Theoretical foundation}

Our main focus is reading women's agency in transforming matinee spaces from purely physical environments into inimitable social spaces. We affirm the positive sense of agency as a capacity to act that is generally empowered by particular relations of subordination (Mahmood 2006, 33-34), or any meaning and motivations that individuals bring to their actions (Kaaber 2005, 14), rather than conceptualizing agency as decision making, direct opposition, response, or resistance to domination or any other forms of observable action (Kaaber 2005; Mahmood 2006; Malmström 2012). Further, as feminist spatial readings question the rise of agency and mostly relate it with the space itself, challenging gender hierarchies emphasizes the promising approach of agency for alternative gender configurations by claiming that 'construction is not opposed to agency; it is the necessary scene of agency (Wrede 2015, 10; Butler 1990, 147).' We examine how women socially constructed/reproduced gazinos through practices connected to women's identity, culture, habits, morals, values, and rituals. Our theoretical framework is based on gender, agency, and lived-experience theories from gender studies, a Lefebvrian 
understanding of social space from spatial studies, and notions of individual, social, and collective memories from memory studies.

Scholars have focused on women and domestic space with respect to women's agency in spatial production. However, spatial production in the public domain of the built environment (for example, in the gazino space) is a less-explored area in gender and architectural studies. Among the few studies with similar concerns in a predominantly Muslim society, Newcomb's (2009) in Morocco, and Singerman's (1996) and Ghannam's (2002) in Egypt explore the daily lives of the lower-middle class and the adaptation of certain modern practices, taking into account such factors as gender, religion, and class. In terms of spatial practices, we see that women are more restricted than men in public spaces in conservative regions. Regarding such research, our study complements the above-noted by reflecting how certain public spaces are hidden/restricted/forbidden for women and shows the power of women's presence and agency in re-creating a social space and building a new terminology in reading this public space. As elaborating how women act out their desires within public knowledge is essential for gender studies, our stance builds on the argument that women need 'to learn how publicly to declare their right to public power' (Heilbrun 1988, 18). We therefore draw on feminist cultural criticism of how women transformed a public space originally produced according to heteropatriarchal understandings. We conceptualize women as active rather than passive agents in producing their spaces in this Turkish context (Gürel 2009). Thus, we query women's lived experiences and active agency to read the public space through the gender lens.

Like space, gender is socially constructed. Any gender, including women and men, are an outcome of a situation rather than a biological fact. As Beauvoir says 'one is not born, but, rather, becomes a woman' ([1946] 1973, 301). In any space, people of different sexes are compelled to act, think, behave, and feel according to their socially constructed gender roles (Butler 1990), which are culturally defined normative ways of behavior appropriate to a person's sex formed through interactions in ways regarded as socially appropriate. Gender identity is a performative consummation compelled by repeating acts over time (Butler 1988), and material space is continuously produced in relation to gendered identities (Baydar 2012, 699). Thus, the uses of space are inevitably informed by these identities and social roles. Because these uses may change within a particular space; however, gendered identities can redefine and be redefined by the social powers and processes in a space (Bagheri 2014, 287). Throughout the production of space, we immediately realize that social powers, their relations, and users' presence (whether materially as a physical body or through imagery) (re)define a space, and that the space is produced by and in relation to this 
behavior (Lips 2010; Kuhlmann 2014). As Rendell (2000, 102) states, 'As a material culture, space is not innate and inert, measured geometrically, but an integral and changing part of daily life, intimately bound up in social and personal rituals and activities.' Grosz (2000) draws attention to gender and space by considering the feminist reoccupation of space, where women previously re-placed or expelled from those places should claim positions of space as their own where they will be able to experiment and produce new possibilities of occupying, dwelling, or living to 'generate new perspectives, new bodies, new ways of inhabiting' (2000, 221). Spain (1993) also points to the spatial segregation of women in physical arrangements that enable women's access (or deny it) to socially valued knowledge, and emphasizes the expandability of spatial institutions in shaping the status of women in society (1993, 137-147). Accordingly, one of the goals of this study is to show 'how gender relations are constituted and experienced and how we think or, equally important, do not think about them' (Flax 1987, 622). The close connection between gendered identities, lived experiences, and constructed space is significant in exploring how women in the ICP's matinee spaces became social agents of these venues, shaping and reshaping them.

This conceptualization of space connects to Lefebvre's definition of 'social space as a social product' ([1974] 1998, 26), which concentrates on the threedimensional perception of space discussed above (representations of space, representational space, and lived space), while including the social factor, which is directly related with the human being. By attributing space a transformative capacity, Lefebvre acknowledges not only that social relations define space but also that space itself may determine social relations. However, Lefebvre also considers social space as a structural matrix within a historically specific dynamic. Although gender issues were not Lefebvre's primary focus, his theoretical approach informs our study of women as both social and active agents in deciphering their contribution to producing space while repeatedly appropriating it.

In addition to gender issues, this study also connects memory to Lefebvre's conceptualization of social space. Nora (1989, 18-19) emphasizes the concept of places of memory (lieux de memoire), incorporating three characteristics: material, symbolic, and functional. These characteristics are both natural and artificial, and available through sensual experience (physical) and linked to abstract elaboration (mental and practical). They evoke multiple senses of the past when used in an alternative historiography, and this conceptualization relates to Lefebvre's three-level production of social space. The significance of the user's lived experience in the built environment transforms a space from the abstract into one that carries meaning. Memory also carries responsibility for the built environment, through shared meanings and values for all society, and in creating places of memory throughout a city. As Huyssen $(2003,1)$ 
notes, 'built urban space - replete with monuments and museums, palaces, public spaces, and government buildings - represent[s] the material traces of the historical past in the present.' These traces are buried in language and dialect, inscribed on plaques, buildings, and battlefields, and woven through a city's visual and literary cultures. Urban places become mediators in creating collective memory, and encompass material (physical existence) and non-material characteristics (traces of uses and their currently attributed meanings) (Huyssen 2003, 3). Whether place is an ordinary object of daily life or a square, park, monument, or building, it has the capacity to turn into a social space through its users' memories. Apart from its physical existence, a space's social layers are attributed by collective memory, which may generate a sense of belonging and collective identity, or by individual/social memories, which can bring to light undocumented uses or experiences in the micro-histories built on those public spaces.

\section{Sources and methods}

To read the layers of social space discussed above, we examined various primary and secondary sources, involving research in personal archives, official documents, newspapers, and popular magazines. Personal archives included photographs of family members spending leisure time in gazino spaces and artists performing on stage. Official documents, included site plans from ICP's different periods and photographs from Izmir Metropolitan Municipality. Articles, advertisements, and even caricatures in national newspapers, and Yeni Asır, a local newspaper, and popular magazines (Hayat and Ses published between 1970 and 1979) were examined in city and national library archives to find information on the community's socio-cultural background and its representation in public life.

As this historically grounded study raises many concerns regarding the position of memory in reading a space's history, we sought oral histories to investigate the social space through users' practices and experiences, thus creating a different directory of history (Danacıoğlu 2009, 140; Neyzi 2011, 2-4). Citing Sangster ([1998] 2003, 87), Corneilse (2009, 54-59) argues that a researcher does not passively gather information from interviewees but is responsible, together with the informant, for constructing the informant's historical memory. Thus, personal narration is the appropriate methodology for sharing women's stories in our study. Derived from Haraway's (1988) embodied feminist objectivity, we challenge binary oppositions of objectivity by clarifying the embodied nature of vision; vision appreciates informants' experiences while considering them knowledgeable agents. Therefore, women are never passive because they are 'experts of their own experiences' (England 2006, 288). Feminists value interaction in their attempt to comprehend informants' understandings of their circumstances in the implemented social 
structure. Parallel to the agency paradigm in theoretical understanding, we also reconsider women's agency and experiences in our methodological approach, which helps to politically ground feminist knowledge to provide a deeper understanding of the subtle nuances of women's everyday lives.

We began with a thematic approach, then detailed the information by narrative analysis. We conducted three informal group sessions of various sizes with women who lived in Izmir during the 1970s and patronized ICP. The sessions included six to 10 participants, ranging from 63 to 82 years old. The participants' recollections reflected how the shift in Turkey's entertainment culture helped to change women's position in the public order and their understanding of matinees, both of which became essential factors in developing these women's agency in public life. Our study draws on a feminist understanding to illuminate numerous factors underlying women's overall interpretations in transforming the gazino into a social space.

After these group sessions, we identified other key individuals (11 men and 6 women) who witnessed or experienced the 1970s gazino spaces and conducted the narrative analysis process with them. This group was identified using snowball sampling, that is, approaching one member of a group to ask for referrals to others knowledgeable on the topic in order to identify individuals who would not otherwise be easily found (Krathwohl 1998, 173). As the interviews were not gender balanced, concentrating only on women casino customers would have been insufficient. It was crucial to find other types of users, visitors, and performers, and from both the evening programs and women's matinees. Accordingly, these interviewees, aged 55-86, came from various social circles of the 1970s: five informants had frequented the matinees while the others included a former owner of a popular Izmir movie theatre, a researcher on Izmir's urban history, the daughter of the head of the infrastructure and construction committee that established ICP, a former gazino owner, a former ICP assistant director, two tabloid journalists prominent at the time, two well-known musicians from the shared orchestras of many gazino artists, and three important gazino stage performers. We conducted face-to-face, indepth, semi-structured interviews in Turkish with open-ended questions, lasting about one hour. We digitally recorded the interviews while also taking notes about any commonalities and differences that surfaced among the interviews. We then downloaded the audio files and translated the interviews into English before writing our post-interview reflections.

In both the group and individual interviews, we allowed participants' voices to be mediated by our analysis of the collected information, while also allowing them to speak directly to the reader. Each interview took its own direction and rhythm; in both types, we aimed to explore ICP users' backgrounds, daily routines, and important life events leading up to their decisions to use ICP's public spaces. To gain a complete narration of how 
women's agency transformed these spaces, we had three groups of openended questions: women's urban leisure-time practices; women's practices in ICP spaces; and women's practices in ICP gazino spaces.

\section{Developments in the entertainment/gazino culture in 1970s' Turkey}

Political events in $1970 s^{\prime}$ Turkey were closely related to the military intervention of 1960, which ended the Democrat Party's (DP) decade-long governance. The party had gained power in 1950 after that year's elections terminated Turkey's one-party era. The first half of the 1960s was considered emancipatory, with its revised constitution allowing more freedom of expression. Meanwhile, the US attack on Vietnam in 1968, which provoked many protests in America and Europe, including revolutionary socialist worker and student movements in France, also strongly affected Turkey, leading to student boycotts, walkouts, labor protests, strikes, and general anarchy (Althusser 1975, 39-49; Ahmad [1995] 2012, 170-173; Tunçay 2000, 174-176; Zürcher 2000, 371-372). The resulting social tension became evident in Turkey's polarized community structure, with people living according to their ideological viewpoints and labeling themselves right-wing, left-wing, Islamist, or nationalist. The tension was also evident in cities, between existing residents and newcomers from rural areas who had been forced from their homes by improvements in local industry that had helped Turkey recover from financial crisis by 1960 (Ahmad [1995] 2012; 142-143). As domestic migration increased in the 1960s and 1970s, squatter belts widened on the fringes of Turkish cities (Ahmad [1995] 2012, 160-161; Zürcher 2000, $391-395)$. According to Kongar $(2002,592)$, one consequence of this shift was the so-called 'arabesque culture,' characterized by the hybrid identities of the new labor class that had migrated to cities hoping for a better life but instead suffered poor economic conditions and difficulties adapting. In studies of arabesque's social significance, it is portrayed as a product of Turkey's transitional period: "an alien and malformed element marginal to society that [was] supposed to fade away as industrialization and urbanization proceed[ed]" (Özbek 1997, 211). This transition had reflections upon in the music industry, starting by the end of 1960 . The musical term arabesk later evolved to describe the entire migrant culture living in Turkish cities (Özbek 1997; Kırık 2014; Soydan 2015) and secured its place in the Turkish entertainment culture, particularly in gazinos.

Defined by social tensions between contradictory political and socio-cultural groups and views, the 1970s embodied both revolt and hope. One significant intervention in social life was television, which arrived first in upperand middle-class households. The state's monopoly broadcasting initially aimed to educate the masses. Television sets became the center of the 
home space, providing local and global news and changing entertainment concepts and practices. While there was a variety of musical styles, many singers and programs were censored for their political views (Tunç [2001] 2015, 171; Bek 2007). By the second half of the1970s, those who could not afford a TV would visit friends or relatives who owned one as a means of socializing rather than people meeting in public spaces. Television thus greatly impacted social life and the home space by changing entertainment and leisure practices (Gürel 2016, 466).

In the summer, those who eat ice cream in tea gardens are rare, family visits in long winter evenings are no more, playing cards with the neighbors is forgotten, and movie theatres are closed. The slow but tasteful life of the individual has completely changed with the black-and-white images of television (Tunç [2001] 2015, 103).

A TV set enabled free entertainment in the convenience of the home. In smaller towns, only better-off families could visit gazinos to watch popular artists. Those without the means or uninterested in gazinos could listen to records, and then, when TV became widespread in the second half of the 1970s, many who found contemporary gazino culture gauche preferred to stay home and watch the same artists on TV. This rising trend in Turkey's major cities of Ankara, Istanbul, and Izmir was a defining moment for the gazino culture. Together with movie theatres, gazinos experienced a decline in popularity at that time, facing extinction. In Izmir, the survivors became concentrated in ICP (Dağtaş 2004, 110). Economic viability became critical for gazino owners, leading them to revive the gazino culture by adapting it to affordable, daytime entertainment (Figure 1). Through this culture shift, gazino matinees for women became a practical means to attract customers and recoup financial losses.

Similar economic concerns plagued the Turkish film industry, called Yeşilçam (Çetin 2014, 290, 307). As television's popularity increased, Yeşilçam filmmakers began to shoot movies with pornographic content to adapt, aiming to at least attract men to movie theatres since families now preferred to watch TV instead of going to the movies. Interestingly, this change helped the gazino business because, according to Nuri Yalçuk, a well-known 1970s gazino owner, gazinos began to collaborate with the Yeşilçam actors who refused to act in erotic movies by employing them as singers (Dağtaş 2004, 117). This feature attracted more people (mostly women) to gazinos during the day and attracted families at night. In a gazino space, whether in a mixed-gender audience or a women's matinee, viewers could now see in person the celebrities they saw and heard on TV, film, and radio (Alkar 2012, 439).

These developments in the entertainment sector reflected Turkey's urban socio-cultural composition in the 1970s. As such, they underlined the shift in gazino culture and in its materiality. Since the 1930s, certain aspects of 


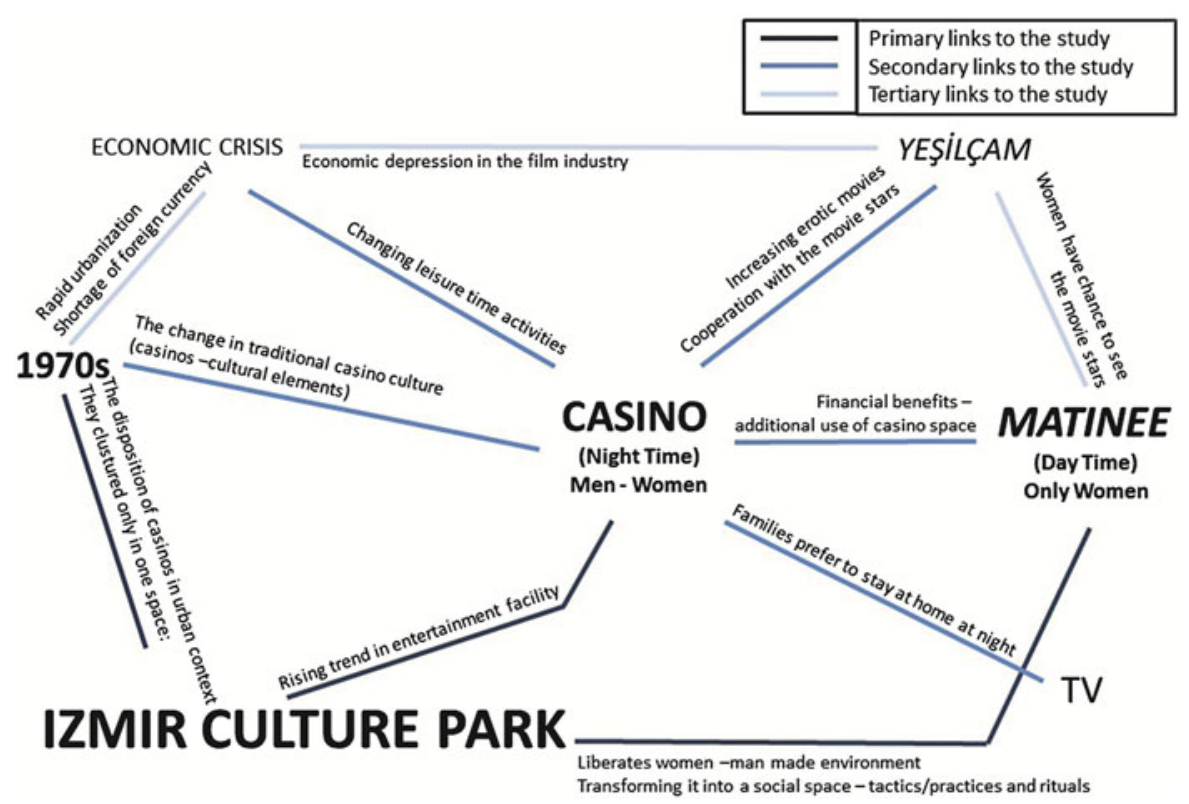

Figure 1. Bounding issues of ICP's entertainment sector in the 1970s, and the related subtopics this study covers. The relations are grouped into three, according to their depth and closeness to the study scope.

gazinos had become standardized, with their identity based on the practice of patrons listening to music while eating a meal (Beken 2003; Dağtaş 2004). However, Izmir's remaining gazinos' identity was not only manifested in supposedly modern modes of behavior but also in the spatiality of ICP, characterized by material objectification of early republican ideology and international modernist aesthetics (Gürel 2011). During the 1970s, many gazinos and entertainment gardens became hybrid spaces, where diverse socioeconomic groups met and a variety of cultural forms, including music ranging from arabesque to Turkish art music, were performed and intermingled. Tunç ([2001] 2015, 171) describes these changes as kitsch: 'Zeki Müren brought the notion of kitsch onto the stage and gained public acclaim.' Müren, a celebrated gay singer of Turkish art music, elaborated the idea of fantasy through his flamboyant and wild costumes, make-up, and stage sets, which made gazino culture even more popular and attractive.

These shifts in Turkish entertainment and leisure practices, which made gazino culture restructure itself, introduced new concepts and new opportunities for people from different social strata, such as the increase in women's matinees. These programs in turn, especially the frequent women's matinees, generated a social space for women patrons to experience a sense of emancipation in the public domain, freed from normative gendered practices. 


\section{Matinees: opening up a space for women}

Widespread use of gazinos for daytime matinees in addition to evening operations featuring the same stars significantly affected the Turkish urban experience, both socially and economically. One consequence was the active participation of women from different social strata in a public space. Beyond providing a site for women to spend their leisure time watching a variety of live musical performers, a matinee was an escape from daily domestic routines. Matinee practices in the ICP rose in the 1950s from its early gazinos and entertainment gardens, frequented by families and women (Dağtaş 2004, 90). Tickets, sold at the door, were usually inexpensive for matinee performances, and there was no meal service. As many seating, as possible, were crammed into the space to maximize capacity and reduce costs.

The concept of the matinee began by offering women-only shows (although children could also attend and often did), typically on Wednesday afternoons, and the same show for women and men at a cheaper Sunday matinee (Figure 2). Going to an evening gazino was a special event for a middle-class family, as it cost a significant amount of money. Therefore, matinees provided the only way some middle-class women could experience a gazino space (Beken 2003). As one interviewee recalled, 'Even if a great artist was on stage in the matinees, it only cost one-third of the regular evening gazino ticket' (Frequenter, woman, age 45-64). However, the demand for matinees went beyond affordability; as we argue, it spoke to a deeper desire in women to open up a public space for themselves. To understand this complexity in the historicity of gazino matinee culture, we need to explore Turkey's sociocultural background before and during the 1970s. This journey requires understanding women's positions in society, their agency in public life, and their representation. The following outlines the foundations of the women's

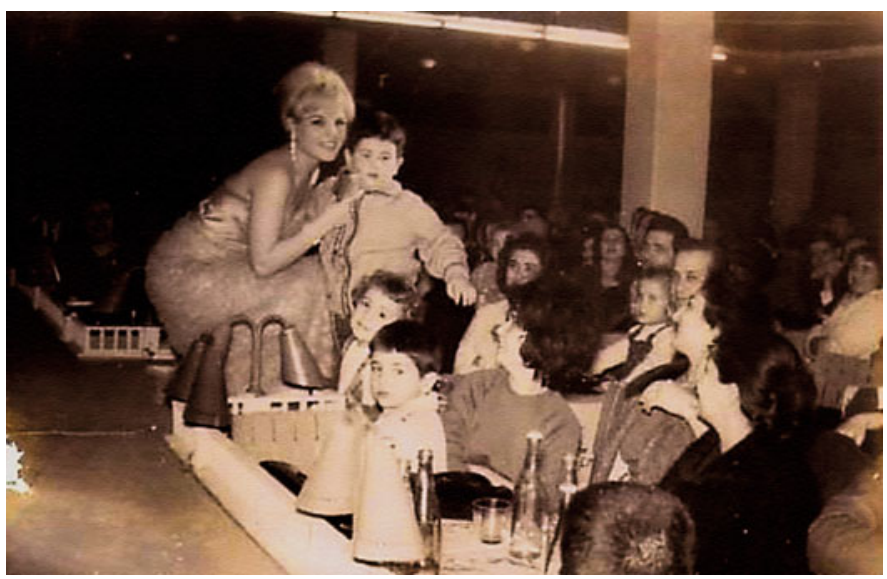

Figure 2. Scenes from a 1970s matinee. Source: https://yavuzhakantok2.wordpress.com/ 2012/01/16/gazino-show-devam-ediyor/. 
movement in Turkey, its involvement in politics during the 1970s, and women's changing representation in popular media as liberal figures.

Turkey's women's movement has late-Ottoman origins, particularly in earlytwentieth-century initiatives regarding fundamental rights, such as denouncing polygamy and repudiation. Despite 50 years of activism, however, women had to wait until the Turkish Civil Code was adopted in 1926 to gain their fundamental civic rights (Tokgöz 1994, 99; Tekeli 2010, 120). In practice, women gained the right to vote in 1930 and the right to stand for public office in 1934. These changes reflected the republican ideology and the worldviews of its founder, Atatürk (1881-1938). Framed within official ideology, discourse on women concerned their rights rather than patriarchal domination in Turkish society. Indeed, it was still too soon, socially and culturally, to challenge the latter and women who did were ignored. As such, the Turkish Women's Union, established in 1924 to advance women's suffrage and equal participation in social life, was asked by the government to disband in 1935, with a belief that it had completed its mission and that there was no longer a need for such an institution. The next organization concerned with gender equality emerged in 1975 (Tekeli 2010, 120), by which time the discourse had changed slightly under the influence of the feminist and leftist movements (Merçil and Senemoğlu 2014, 17-23). It is no coincidence that international women's movements were also launched in this era (Knaus 2007, 2). The 1970s have been described as a period when Turkish women were not truly acting as feminists and were also more concerned with the difficult conditions of working-class women (Tekeli 2010, 120). As elsewhere, more women were entering public life through work or occupying the public space; hence, they fought for the same rights as men. Within the politicized character of a left/right dichotomy and the labor movements, Turkish right-wing parties' gender-related policies imagined women primarily as wives and mothers, whereas, apart from issues of the working class concerning men and women, left-wing parties offered no particular agenda regarding women (Tokgöz 1994; Bek 2007, 31). Consequently, women's positions in society embodied both continuation of and change from previous periods. These shifts later led to modifying the patriarchal relations found in left-wing movements.

One can argue that the increased representation of women in the public arena was a response to the rebellious socio-political background of the 1970s. Popular media often portrayed young urban women as liberal figures, contesting the idealized images of housewives from earlier eras. The new stylized, upper-middle-class woman of this time is well exemplified in a pantyhose advertisement showing a young woman wearing a strapless mini dress while sitting confidently in a chair under the slogan 'Free to do as she pleases' (Figure 3). The beliefs embodied in such representations hint at 


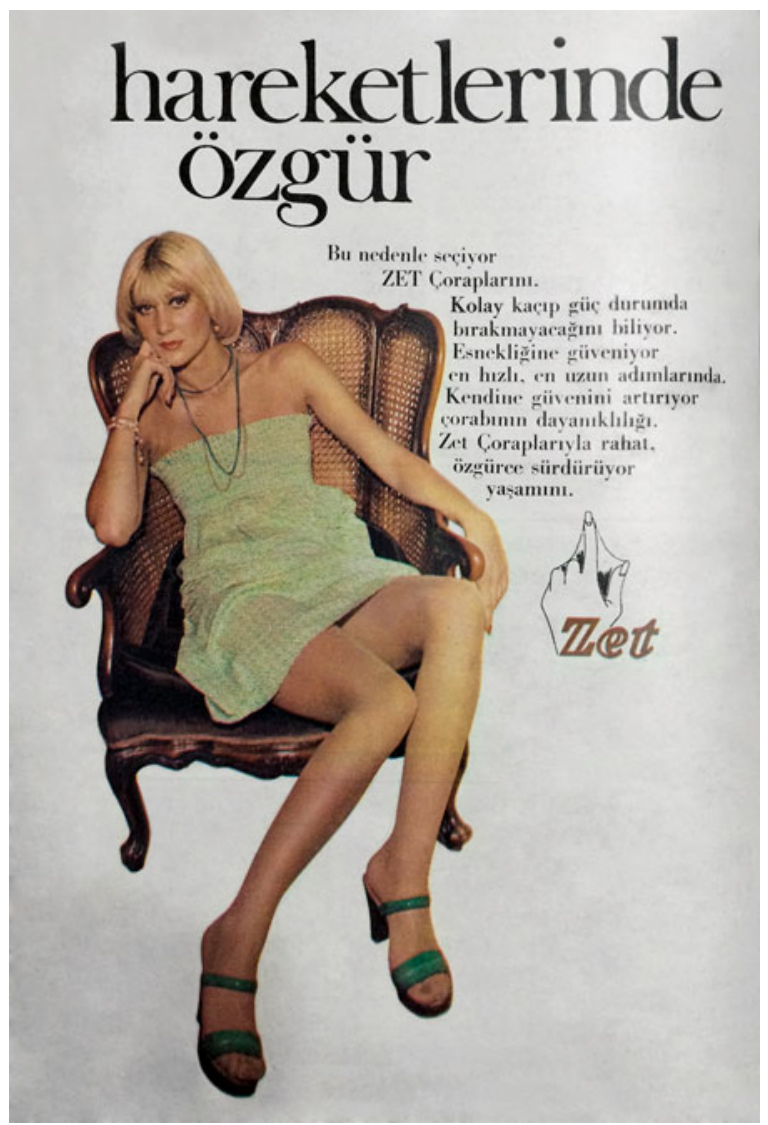

Figure 3. A pantyhose advertisement from the early 1970s, Hayat Journal.

urban middle- and upper-middle-class women's yearnings for identities and practices beyond housewife and mother.

Although still very much defined by their expected social roles, many women assumed a strong presence in public life, particularly through escaping from the home to enjoy more leisure activities in the public domain. As an interviewee explained:

Beer was served in cafes; men and women sat together and drank beer. Izmir people were very civilized regarding male-female relationships .... Women were able to live freely and as they no longer had to seclude themselves at home, matinee spaces became a need. Women were going out, dancing, and even drinking alcohol (Former gazino owner, man, age 65+).

However, many women did not attend gazinos. Some could not afford it, some were single or widowed and felt uncomfortable participating in evening public life unaccompanied by a man from the family, and others preferred to watch performers on TV when it entered the home space. These factors still confined the majority of women to the domestic space, especially 
those who did not work outside the home. The matinee was thus a mechanism to challenge this gendered public/private dichotomy by establishing a liminal position that gave women the possibility to be in a public space of their own choosing at a time and context when urban women were still heavily restrained by gendered roles and continued to enact stereotypically.

\section{Reproduction of the matinee as a lived experience}

The oral histories carried out for this study indicate that matinee spaces allowed women to develop and/or strengthen social bonds with other women, such as relatives, neighbours, and friends, similar to functions such as weddings, graduations, and religious classes (Abbas and van Heur 2014, 1219-1220). However, relations and practices in the former were less stable than in the socially controlled environments of the latter. Through meeting others outside their everyday context, women received respite from the usual male-dominated power relations. Regarding current debates in radical feminist theory questioning whether women-only spaces encouraged women's empowerment or revitalized the subordination of women within the social structure, our study shows that matinee spaces were profoundly important in prioritizing women's needs.

As gazino spaces transformed into matinee spaces, they changed character from a public to an alternative space, enabling alternative practices and/or boundary transgressions. In terms of the Lefebvrian triad of social space, while the gazino's physical set-up constituted the conceived space, the audience's feelings, sensations, and memories occupied the perceived space, and women's agency occupied the experiences of the lived space. According to Allen (1999), lived space is produced from conceived space, as the latter acts against the homogenizing influences of conceived space. However, it does not exist without the other two elements of social space. In a social space, power is operationalized as production, exclusion, and reproduction (Allen 1999). Such spaces are reproduced and gain meaning through the agency of the women occupying them and perceived in a new way through their lived experiences. Thus, women's agency in the reproduction of the gazino space can be analyzed within four categories: experiencing the space through bodily senses (sight, touch, sound, smell, hearing), describing new social bonds (interaction, connection, and communication), applying rituals (beyond daily life), and liberating themselves from gender normativity.

From the creator's perspective, the gazino matinee's conceived space focused on putting distance or establishing a hierarchy between the performer and the women (performer on stage; audience on the floor), whereas the perceived space aroused admiration for the artist on the stage. 


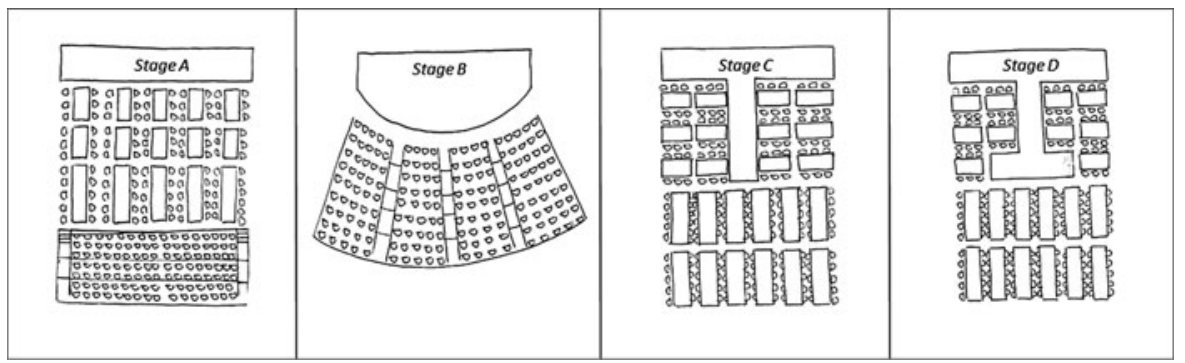

Figure 4. Plan sketches showing different stage designs, drawn according to spatial descriptions by interviewees. The extended stage design was used for creating more intimacy between the artist and the audience.

The transformation of the stage area is one example of such practices reflecting women's agency (Figure 4).

The stage was designed as a segregated area for the performer and orchestra but publicly visible. Set high off the ground, it put both physical and metaphorical distance between the performer and audience, thereby establishing a boundary strategically designed to emphasize the performer's high social status and trigger admiration. Though the stage was under surveillance in the conceived space through its design strategies, it allowed alternative practices through women's agency, which appeared through the relationship between performers and their audiences. Several oral histories described these practices and relationships:

Women usually clapped with the music to accompany the singer[s, who] had a large orchestra behind them on the stage, [which was] shaped like a semi-circle with a peninsula extending into the audience. That shape was Zeki Müren's invention. It helped the artist mingle freely with the crowd, and the audience could write down a song they wanted on a piece of tissue and pass it to the artist while he or she walked along the stage (Frequenter, woman, age 65+).

Although the T-shaped stage limited physical contact between audience and singer, it allowed greater emotional contact, stimulating sight, smell, and touch, as noted by a patron and a singer, respectively:

I could never forget Ismet Nedim's light green suit and pink shirt... [or] Sevim Devran's evening gown.... Singers put perfume on every part of their costumes. When they walked along the stage, you could smell it, and consequently you perceived the singer as beautiful, clean, elegant, and untouchable (Frequenter, woman, age 45-64).

I used to have perfume put on the fan blowing towards the audience before I stepped onto the stage. I also poured almost a whole bottle of perfume on myself, especially onto the hem of my dress. The audience could smell it as I walked on the stage (Singer, woman, age 45-64). 
Although owners, managers, designers, and administrators affiliated with ICP or Izmir municipality regulated the physical condition of the gazino, our interviews showed that women adjusted to the physical spatial conditions through tactical solutions, thus transforming the space. Some rented cushions from the gazino, while others brought cushions from home to improve the basic seating. They also brought meals and snacks, which they enjoyed sharing. If there were no tables, women brought portable furniture for their plates. They used the aisle steps for extra seating or dancing, and many danced on seats and tables. Thus, the limited conditions of the conceived space were enriched by the users' needs and practices:

The tables were crowded in to accommodate demand.... Some people liked to go earlier to keep a place.... [T] he belly dancers danced not only on the stage but also all around the tables, and the women would put some money in the dancers' dresses. If there was not enough space, you could ask a dancer to dance on top of your table. Sometimes, the singer would come beside you and hold the microphone to the woman to accompany him/her. Plus, women used to dance with the artist on the stage or all together across the auditorium, between the tables and seats (Frequenter, woman, age 45-64).

Our interviewees remarked that, although these women were clearly aware of the environment's physical characteristics, such as the stage design, furniture layout, spatial quality, and architectural details, they seemed to care more about the structure of social relations.

As Brenner $(1997,140)$ suggests, and as implied by women's practices in the gazino, Lefebvre considers space as a matrix of social action - regardless of the physical characteristics - at once a presupposition, medium, and product of social relations. For example, many layers of interactions occurred between the gazino artists and the women, and among the women themselves, in building social links in the matinee space. Users' memories demonstrate the significance of these connections in turning abstract space into a vivid, living space:

Once, in a matinee, my mother liked the dress of the local singer on stage. While she was asking around who could sew a dress like that, someone from the next table told us that she was the singer's tailor.... My mother took the tailor's phone number and address, and later she made a dress for my mother (Frequenter, woman, age 45-64).

As this anecdote and others show, women attending the matinees often became acquaintances and friends, treating each other to home-cooked food, meeting, interacting, and exchanging what they brought from their social backgrounds into these spaces. These practices coincide with Ortner's position on agency, in that she relates the notion of sparkling with specific desires and intentions within a matrix of culturally constituted feelings, thoughts, and meanings $(2005,41)$. According to the narrations, during short 
breaks between performances, some women passed the time performing culturally constituted gender practices such as knitting, or sharing knitting patterns and recipes. Regarding specific individual desires, if someone liked another woman's outfit, she could arrange for the same one to be made and receive it at the next performance.

As an important tool of building social bonds and memories, women also liked to capture their feelings from the matinee experience by having their pictures taken, especially with the star performer (Beken 2003). Portraying gazino practices with social actors in the background, these images speak to the ritual quality of practices in this space, brought alive by the participants' oral histories. Attending a matinee was important in women's (and their children's) lives, involving planning, preparation, and performance that started in the private domestic space and ended in the public space of the gazino. Since attending an ICP matinee was considered an important event, women followed various rituals, customarily waking up early on matinee day to complete their food and dress preparations. People arrived at the gazino hours before the show, queuing to secure a front-row seat. Before the performance, the usual routine included renting and positioning cushions, eating sunflower seeds, and drinking soda. People from different socioeconomic backgrounds and diverse city districts met at the gazino, and some turned the outing into a full-day event by staying for the evening program. One interviewee who attended matinees as a child with his mother described how the space was used:

Though Wednesday was the usual day for matinees, some also occurred... on Fridays and Saturdays. Generally, the upper classes did not attend matinees. In our family, women relatives went together to the matinee and younger members ... studying in high school or university joined them [later] to catch the end of the show. After the matinee, we waited for the male members of the family to join us for the evening program. Families did not get back to their homes before midnight. Many families did this and so got to know each other (Frequenter, man, age 45-64).

The gazino entertainment culture was thus a catalyst for diversion from a family's daily routine; whether to escape domestic life, school, or work, it characterized the urban experience at the time and place. However, matinee practices and their perceived importance were more significant for women because they supported what was not then usually attributed to them: a space of liberation. Matinees enabled women, most of whom were limited to domestic life and its incessant household chores, to break from their prescribed roles and become part of the variegated social environment. Children played freely as their mothers danced and socialized, and made friends that they may have only seen at gazino events. Some interviewees found the matinees friendlier and with a warmer public quality than the 
evening shows. Further, as one attendee explained, in turning the gazino space into a matinee place, women liberated themselves from men's control over their lives:

Some women went to matinees without telling their husbands because some men could get angry at their wives for going. Therefore, although they were housewives [suggesting they did not earn money or have an income of their own], they paid from their savings on home expenses (Frequenter, woman, age 65+).

Thus, the inner, hidden, or secret self of women who usually followed conventional forms and acted in gendered and respectable ways in their daily life, emerges (Malmström 2012). In some cases, women enjoyed close contact with male performers, dancing with them, feeding them homemade snacks, or throwing flowers on the stage to get their attention (Figure 5). This level of intimacy is described in a 1964 newspaper article:

Suddenly you realize there is a young woman on the stage, wiping [the singer's] sweat [from his forehead] while holding his arms. Then she kisses her chiffon handkerchief while showing it to everyone and places it between her breasts. On his next step ... a braver woman hugs and kisses this 'holy baby.' Others follow.... The crowd cheers as if the whole audience has kissed the same cheek, touched the same skin (Yeşim 1964).

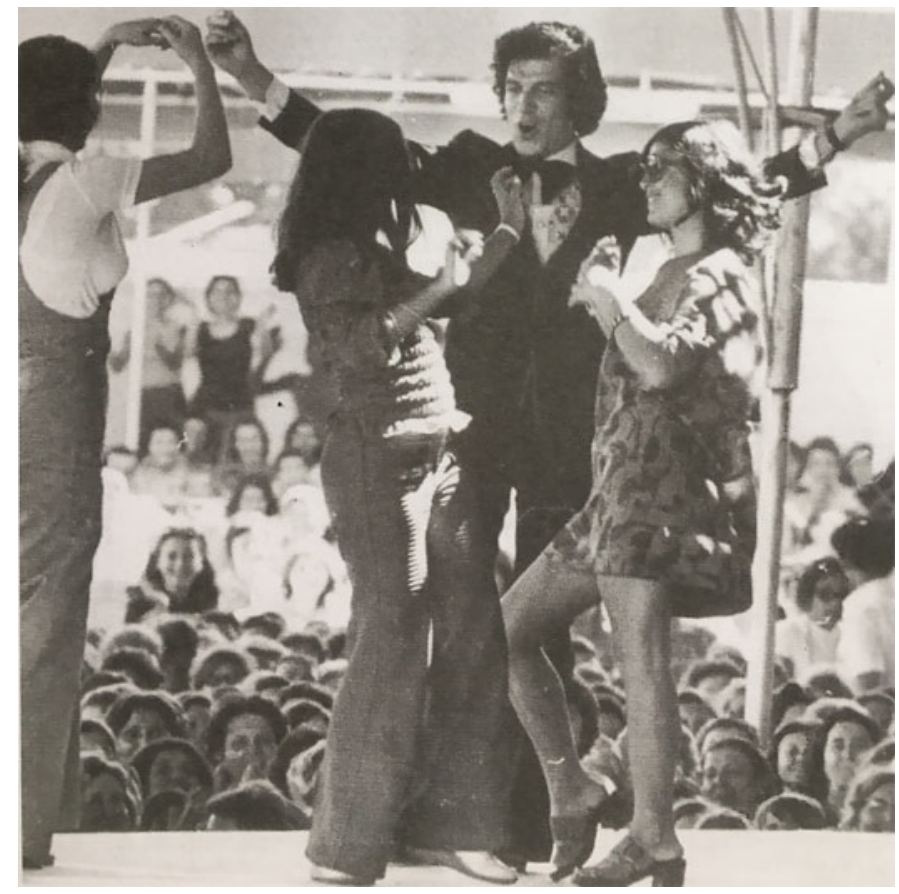

Figure 5. Woman dancing with the famous Yeşilçam actor/ singer, Izzet Günay, on stage during a matinee. Source: Göçmenoğlu, Tayfur. 2008. Bir Magazin Nostaljisi: O Yıldızlar Hiç Sönmesin, edited by Ferda Uygur. Izmir: Belsan. 
By the 1970s, such actions that had transformed the conceived gazino space defined the matinee experience. To overcome the boundary between singer and audience, women created their own connections to the stage, either physically, by jumping up on it or, symbolically, by throwing their belongings on it. Some women smoked, and even drank during the matinees, although at that time it was risky to do so in public or if older male relatives were present:

I saw some women pour alcohol into their lemonade or orange juice under the table in matinees. Although few in number, some businesses served alcoholic beverages. That was a big event for Turkey in those times (Former assistant director of ICP, man, age 45-64).

Such transgressive actions demonstrated an urge for liberation and increased the demand for matinees. Women brought these culturally disfavored and dishonorable acts into the public sphere rather than hiding their secret selves. Such new, 'daring' actions draped over the conceived space of the gazino allowed women to challenge and step beyond normative gender roles, as suggested by the aforementioned pantyhose motto, 'Free to do as she pleases' (Figure 6). In short, the matinee practices discussed here reflected that time's sense of revolution for women, creating social bonds and opening a gap - a

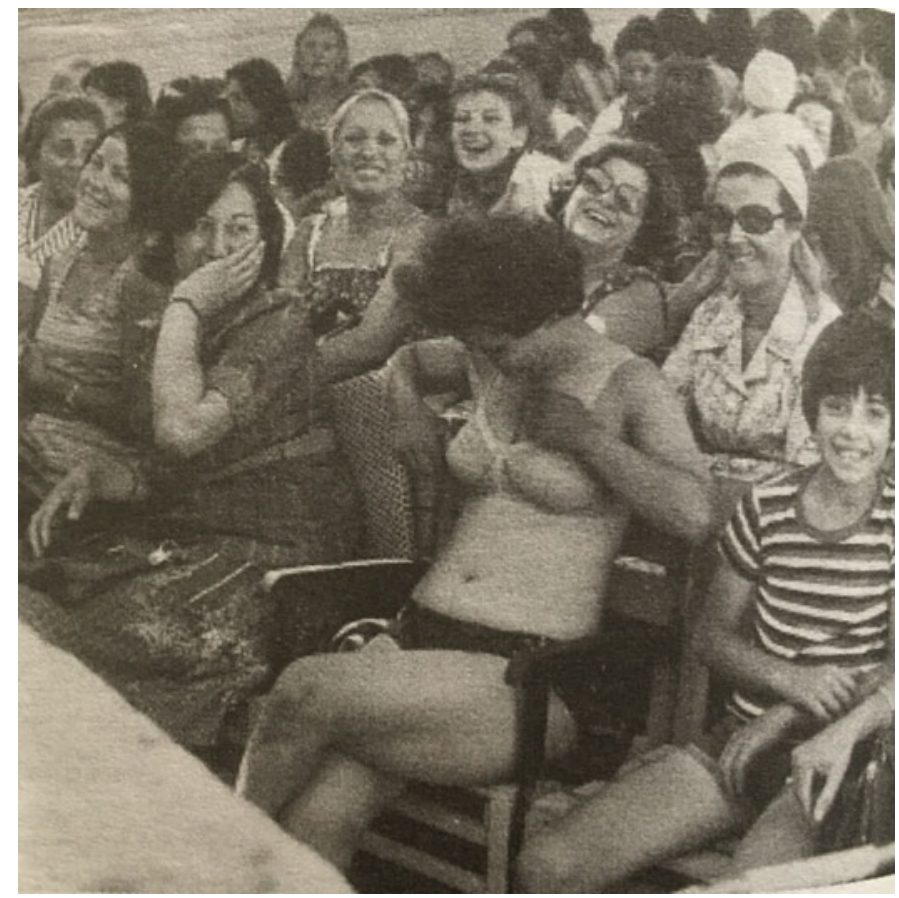

Figure 6. A woman challenging gendered norms in matinee under the stunned gaze of other women patrons by removing her shirt. Source: Tayfur Göçmenoğlu (2008), Bir Magazin Nostaljisi: O Yildizlar Hiç Sönmesin. Izmir: Belsan Publications. 
liminal space - for challenging social norms and escaping from the daily routines defined by their assumed social roles.

\section{Conclusions}

From its establishment in the 1930s, ICP represented Turkey's national identity and connection to the international community. Its materiality expressed contemporary modern aesthetics, and its leisure and entertainment spaces celebrated modern values and conditions while functioning as a medium for adapting them. Our study underscores the significance of analyzing public space in relation to local historical contexts to show social changes and gaps in challenging norms, beliefs, and values. It also analyzes personal experiences within the local historical context to render their interplay distinguishable economically, politically, and culturally (McNay 2004). Although participants' recollections could portray a rosy view of the past, we maintain that 'memory and recovery [do] not have to take the form of nostalgia' (Massey 1994, 123). Our study strengthens its argument by establishing strong links to archival research in exploring how socio-economic constraints and events during the 1970s affected Turkey's entertainment culture, as well as how ICP's gazino spaces were hybridized, diverging from their earlier cultural forms and modern aesthetics. Although this hybridism is often considered eclectic and kitsch, centered on an arabesque culture, our study investigates those years through the perspectives of the novelties and opportunities created by the period's social and political tensions. By problematizing women's performances in entertainment spaces, our article shows that, within ICP's historicity, the 1970s represents a breaking point, when gazino culture became freer and more accessible to different social strata while offering women an opportunity to escape their domestic environment. It redefined the concept of gender and performance as a 'constituted social temporality' (Butler 1990), and allowed women to experience an alternative public space - a safe zone - in which to live out their modernity.

The gazino culture discussed here gradually disappeared in subsequent decades because most singers started performing in assembly halls or auditoriums, as it became more acceptable for women to be in the public space. However, women's matinee practices led the way for this shift by turning a physical space into a social space through socially reproducing contemporary spatial codes. In so doing, women opened up an alternative space in which to liberate themselves through applying their own rituals and tactics, thereby adding new layers of meaning to ICP's historicity in terms of women's spatiality.

Through their matinee practices, women could abdicate their daily responsibilities, breaking the shackles of imposed moral values, family, and social 
relationships and producing new possibilities through their own ways of experiencing a space. The interviewees' recollections show us how subjects' lived experiences connect to women's agency within a space while rendering normative gendering practices. Within the matinees' limited spatial and temporal existence, women pushed back the built environment's constraints to move beyond everyday life boundaries through their shifting practices of communicating, eating and drinking, dancing, getting dressed up, building friendships, and sharing. Gazino practices catalyzed women's empowerment, helping them break free from gender constraints to achieve actualization (Wrede 2015, 10). As agents of transformation in the matinee space and in producing their own social space, women not only liberated themselves from the ideals of a conventional wife, mother, and/or daughter by changing their fantasies but also altered some indicators of social and moral norms. Perhaps this is why artists like Zeki Müren, blatantly transgressing gender lines with his outrageous costumes, resonated with women, who celebrated his daring performances. Like some performers, in the gazino women found a temporary sanctuary from Turkey's social constraints and gendered power relations.

\section{Acknowledgments}

We would like to thank this study's participants who generously shared their memories with us. We also thank Dr. Kanchana N. Ruwanpura and the anonymous reviewers for their valuable suggestions.

\section{Disclosure statement}

No potential conflict of interest was reported by the authors.

\section{Notes on contributors}

Meltem Eranıl Demirli received her PhD degree from Bilkent University in Ankara. She is giving lectures as an assistant professor at Yasar University in Izmir. She attained a patent with her graduation project, a portable post-disaster shelter unit, from the Scientific and Technological Research Council of Turkey (TUBITAK) in 2013.

Meltem Ö. Gürel is a professor at Yasar University. She previously taught and served as the founding Chair of the Department of Architecture at Bilkent University. Gürel received her $\mathrm{PhD}$ in Architecture from the University of Illinois at Urbana-Champaign (UIUC). Her research interests include architectural theory and criticism, cross-cultural histories of architectural modernism with an emphasis on society, gender, and culture (especially in midtwentieth-century Turkey), culture-space relationship, and design education. Dr. Gürel has published numerous articles in leading journals, including Journal of Architecture; Journal of Architectural Education; Journal of the Society of Architectural Historians; Journal of Design History; Journal of Architectural and Planning Research: and Gender, Place and Culture. Her work has also been published in many collections. She is the editor of Mid-Century Modernism in Turkey: Architecture across Cultures in the 1950s and 1960s (Routledge, 2016). 


\section{References}

Abbas, Mokarram, and Bas van Heur. 2014. "Thinking Arab Women's Spatiality: The Case of 'Mutanazahat' in Nablus, Palestine." Gender, Place and Culture 21 (10): 1214-1229.

Ahmad, Feröz. [1995] 2012. Modern Türkiye'nin Oluşumu. Istanbul: Kaynak Publications.

Alkar, Ruşen. 2012. "Nostalgia of Zeki Müren In The Case of Izmir Women's Matinee." The proceeding of $1^{\text {st }}$ International Music Studies Symposium, October 24. http://www.ktu. edu.tr/dosyalar/56_00_00_62f40.pdf

Allen, Lee Ricky. 1999. "The Socio-Spatial Making and Marking of 'Us': Topward a Critical Postmodern Spatial Theory of Difference and Community." Social Identities 5 (3): 249-277.

Althusser, Pierre Louis. 1975. "1968 Mayıs Olayları Üzerine Bir Mektup." Translated by Taciser Belge. Birikim (1): 39-49.

Bagheri, Nazgol. 2014. "Mapping Women in Tehran's Public Spaces: a Geo-Visualization Perspective." Gender, Place and Culture 21 (10): 1285-1301.

Baydar, Gülsüm. 2012. "Sexualised Productions of Space." Gender, Place and Culture 19 (16): 699-706.

Beauvoir, de Simone. [1946] 1973. The Second Sex. New York: Vintage Books.

Bek, Güler. 2007. "1970-1980 Yılları Arasında Türkiye'de Kültürel ve Sanatsal Ortam.” PhD diss., Hacettepe University.

Beken, Münir Nurettin. 2003. "Aesthetics and Artistic Criticism at the Turkish Gazino." Journal of Musical Anthropology of the Mediterranean (8): 8-19. http://umbc.edu/MA/ index/number8/gazino/bek_00.htm

Bengi, Derya. 2014. "Hayat, Memat, Pop Art." In Işste Benim Zeki Müren, edited by Derya Bengi, 15. Istanbul: Yapı Kredi Culture and Arts Publishing.

Brenner, Neil. 1997. "Global, Fragmented, Hierarchical: Henri Lefebvre's Geographies of Globalization." Duke University Press Journals 10 (1): 135-167.

Butler, Judith. 1988. "Performative Acts and Gender Constitution: An Essay in Phenomenology and Feminist Theory." Theatre Journal 40 (4): 519-531.

Butler, Judith. 1990. Gender Trouble: Feminism and the Subversion of Identity. London: Routledge.

Corneilse, Carol. 2009. "Living Feminism in the Academy: South African Women Tell Their Stories." PhD diss., University of Maryland.

Çetin, Derya. 2014. "1970'Lerde Sinema Endüstrileri ve Yeşilçamın Krizi." In Modernizmin Yansımaları: 70'li Yıllarda Türkiye, edited by R. Funda Barbaros and Erik Jan Zürcher. Ankara: Efil Publications.

Dağtaş, Lütfü. 2004. Izmir Gazinoları: 1800'Lerden 1970'Lere, 5-117. Izmir: Izmir Metropolitan Municipality Cultural Publications.

Danacıoğlu, Esra. 2009. Geçmişin Izleri Yanıbaşımızdaki Tarih lç̧in Bir Kılavuz. Istanbul: Tarih Vakfı Yurt Publishes.

England, Kim. 2006. "Producing Feminist Geographies: Theory, Methodologies and Research Strategies." In Approaches to Human Geography, edited by Stuart Aitken and Gill Valentine, 286-297. London: Sage Publications.

Feyzioğlu, Elvan. 2011. Fuar Bizim Hayatımız. Izmir: IZFAŞ Kültür Yayını.

Flax, Jane. 1987. "Postmodernism and Gender Relations in Feminist Theory." Signs: Journal of Women in Culture and Society 12 (4): 621-643.

Ghannam, Farha. 2002. Remaking the Modern: Space, Relocation and the Politics of Identity in a Global Cairo. Berkeley, CA: University of California Press. 
Göçmenoğlu, Tayfur. 2008. In Bir Magazin Nostaljisi: O Yıldızlar Hiç Sönmesin, edited by Ferda Uygur. Izmir: Belsan.

Grosz, Elizabeth. 2000. "Woman, Chora, Dwelling." In Gender, Space, Architecture. New York: Routledge.

Gürel, Meltem Ö. 2009. "Defining and Living Out the Interior: The 'Modern' Apartment and the 'Urban' Housewife in Turkey during the 1950s and 1960s." Gender, Place \& Culture 16 (6): 703-722.

Gürel, Meltem Ö. 2011. "Architectural Mimicry, Spaces of Modernity: The Island Casino, Izmir, Turkey." The Journal of Architecture 16 (2): 165-190.

Gürel, Meltem Ö. 2016. "Designing and Consuming the Modern." In Routledge Companion to Design Studies, edited by Fionna Fisher and Penny Sparke, 457-468. New York: Routledge.

Haraway, Donna. 1988. "Situated Knowledges: The Science Question in Feminism and the Privilege of Partial Perspective." Feminist Studies 14 (3): 575-599.

Heilbrun, Carolyn G. 1988. Writing a Woman's Life. New York: Ballentine Books.

Huyssen, Andreas. 2003. Present Pasts: Urban Palimsests and the Politics of Memory, 1-29. Stanford, CA: Stanford University Press.

Kaaber, Naila. 2005. "Gender Equality and Women's Empowerment: A Critical Analysis of the Third Millenium Development Goal." Gender and Development 13 (1): 13-24.

Kırık, Ali Murat. 2014. "Birth and Development of Arabesque in Turkish Cinema." Gumushane University E-Journal of Faculty of Communication 2 (3): 90-117.

Kolluoğlu, Biray. 2007. "Cityscapes and Modernity: Smyrna Morphing into Izmir." In Ways to Modernity in Greece and Turkey: Encounters with Europe, 1850-1950, edited by Anna Frangoudaki and Çağlar Keyder, 217-235. London: I.B. Tauris.

Kongar, Emre. 2002. 21. Yüzyılda Türkiye: 2000'li Yıllarda Türkiye'nin Toplumsal Yapısı. Istanbul: Remzi Bookstore.

Knaus, Katherina. 2007. "Turkish Women: A Century of Change." Turkish Policy Quarterly 6 (1): 47-59.

Kuhlmann, Dörte. 2014. Gender Studies in Architecture: Space, Power and Difference. New York: Routledge.

Krathwohl, David R. 1998. Methods of Educational and Social Science Study: An Integrated Approach. Boston, MA: Addison-Wesley Educational Publishers.

Lefebvre, Henri. [1974] 1998. The Production of Space. Oxford: Blackwell.

Lips, Hilary M. 2010. A New Psychology of Women, Gender, Culture and Ethnicity. Boston, MA: McGraw-Hill.

Mahmood, Saba. 2006. "Feminist Theory, Agency, and the Liberatory Subject: Some Reflections on the Islamic Revival in Egypt." Temenos 42 (1): 31-71.

Malmström, Maria Frederika. 2012. "Gender, Agency, and Embodiment Theories in Relation to Space." Egypte/Monde Arabe 9: 21-35.

Massey, Doreen. 1994. "Place and Identity." In Space, Place and Gender, 115-175. Minneapolis, MN: University of Minnesota Press.

McNay, Lois. 2004. "Agency and Experience: Gender as a Lived Relation." Sociological Review 4 (2): 139-148.

Merçil, Ipek and Osman Senemoğlu. 2014. "The Historical Grounds of the Turkish Women's Movement." Human and Social Studies 3 (1): 13-27.

Neyzi, Leyla. 2011. Nasıl Hatırlıyoruz? Türkiye'de Bellek Çalışmaları. 2-4. Istanbul: Türkiye Iş Bankası Publishers.

Newcomb, Rachel. 2009. Women of Fes: Ambiguities of Urban Life in Morocco. Philadelphia, PA: University of Pennsylvania Press. 
Nora, Pierre. 1989. "Between Memory and History: Les Lieux de Memoire." Representations 26: 7-24.

Ortner, Sherry B. 2005. "Subjectivity and Cultural Critique." Anthropological Theory 5 (1): 37-66.

Özbek, Meral. 1997. "Arabesk Culture: A Case of Modernization and Popular Identity." In Rethinking Modernity and National Identity in Turkey, edited by Sibel Bozdoğan and Reşat Kasaba, 211-231. Seattle, WA: University of Washington Press.

Rendell, Jane. 2000. "Gender, Space: Introduction." In Gender, Space, Architecture, edited by Jane Rendell, Barbara Penner, and lain Borden. New York: Routledge.

Sangster, Joan. [1998] 2003. "Telling Our Stories: Feminist Debates and the Use of Oral History." In The Oral History Reader, edited by R. Perks and A. Thomson, 85-100. London: Routledge.

Singerman, Diane. 1996. Avenues of Participation: Family, Politics, and Networks in Urban Quarters of Cairo. Princeton, NJ: Princeton University Press.

Soydan, Ersoy. 2015. "The Role of Television at the Gentrification of Arabesque Music." Marmara Journal of Communication 23: 61-73.

Spain, Daphne. 1993. "Gendered Spaces and Women's Status." Sociological Theory 11 (2), 137-151.

Tekeli, Şirin. 2010. "The Turkish Women's Movement: A Brief History of Success." Quaderns de la Mediterania 14: 119-123.

Tokgöz, Oya. 1994. "Kadın Seçmen Imgesi: Türkiye'de Kadının Bireysel Siyasal Katılımı Üzerine Bir Deneme." Journal of AMME Idaresi 27 (4): 97-115.

Tunç, Ayfer. [2001] 2015. Bir Maniniz Yoksa Annemler Size Gelecek. Istanbul: Can Publications.

Tunçay, Mete. 2000. "Siyasal Tarih (1960-1980)." In Türkiye Tarihi 4- Çağdaş Türkiye 1908-1980, edited by Sina Akşin. Istanbul: Cem Publications.

Wrede, Theda. 2015. "Introduction to Special Issue 'Theorizing Space and Gender in the $21^{\text {st }}$ Century."' Rocky Mountain Review 69 (1): 10-17.

Yeşim, Nazan. 1964. "Zeki Müren Haftada 1 Gün 4000 Kadını Çılgına Çeviriyor." Milliyet Weekend Supplement, July 19. http://gazetearsivi.milliyet.com.tr/Ara. aspx? araKelime $=$ mukaddes $\% 20$ bebek\&isAdv $=$ false.

Zürcher, Erik Jan. 2000. “Demokrat Parti iktidarı, 1950-1960." In Modernleşen Türkiye'nin Tarihi, edited by Berna Akkıyal. Istanbul: lletişim Publications. 